\title{
PERAN BRAND IMAGE DALAM MEMEDIASI PENGARUH KUALITAS PRODUK TERHADAP NIAT BELI ULANG
}

\author{
Ketut Joni Santika ${ }^{1}$ \\ Kastawan Mandala ${ }^{2}$ \\ ${ }^{1,2}$ Fakultas Ekonomi dan Bisnis, Universitas Udayana (Unud), Bali, Indonesia \\ email: jonisantikaaa@gmail.com
}

\begin{abstract}
ABSTRAK
Penelitian ini dilakukan pada konsumen yang sudah pernah membeli produk minuman isotonic Mizone di Kota Denpasar. Jumlah sampel yang digunakan dalam penelitian ini adalah sebanyak 120 responden, dengan metode purposive sampling. Pengumpulan data dilakukan melalu ikuesioner. Teknik analisis yang digunakan adalah analisis jalur (path analyze). Berdasarkan Data responden yang secara langsung dapat dilihat bahwa: (1) kualitas produk berpengaruh positif dan signifikan terhadap brand image; (2) kualitas produk berpengaruh positif dan signifikan terhadap niat beli ulang; (3) brand image berpengaruh positif dan signifikan terhadap niat beli ulang; (4) brand image berperan sebagai variabel mediasi antara variabel kualitas produk dan niat beli ulang. Temuan penelitian ini menyimpulkan bahwa kualitas produk berpengaruh positif dan signifikan terhadap brand image dan niat beli ulang konsumen terhadap produk minuman isotonic Mizone di Kota Denpasar, brand image mampu memediasi kualias produk terhadap niat beli ulang.
\end{abstract}

Kata kunci:brand image, kualitas produk, niat beli ulang

\begin{abstract}
This research was conducted on consumers who have already purchased isotonic Mizone beverage products in Denpasar City. The number of samples used in this study were 120 respondents, with a purposive sampling method. Data collection was carried out through questionnaires. The analysis technique used is path analysis (analyze path). Based on respondents' data, it can be directly seen that: (1) product quality has a positive and significant effect on brand image; (2) product quality has a positive and significant effect on repurchase intention; (3) brand image has a positive and significant effect on repurchase intention; (4) brand image acts as a mediating variable between product quality variables and repurchase intention. The findings of this study conclude that product quality has a positive and significant effect on the brand image and consumer repurchase intention on isotonic Mizone beverage products in Denpasar City, the brand image is able to mediate the quality of the product against repurchase intention.
\end{abstract}

Keywords: brand image, product quality, intention to repurchase 


\section{PENDAHULUAN}

Berkembangnya kehidupan modern masyarakat kota saat ini membawa konsekuensi pada gaya hidup yang dijalani. Gaya hidup masyarakat kota dapat dilihat dari aktifitas keseharian,kebutuhan hidup,mode yang dipakai dan lain sebagainya. Kebutuhan manusia menurut tingkat kepentingannya (intensitasnya), salah satunya adalah kebutuhan primer yaitu makanan, minuman, pakaian dan kesehatan.Kebutuhan primer merupakan kebutuhan yang mutlak harus dipenuhi terutama minuman (Maslow, 2007;80)

Perusahaan dituntut untuk terus meningkatkan kualitas produk dan terus berinovasi menciptakan berbagai macam inovasi produk yang mampu memenuhi kebutuhan dan keinginan dari masyarakat. Perusahaan perlu mempelajari dan mengidentifikasi faktor-faktor yang akan mengarahkan perusahaan untuk sukses (Fouladivanda et al., 2013). Perusahaan harus dapat memberikan kualitas yang sesuai dengan kebutuhan dan keinginan konsumen dengan memperhatikan standar-standar kualitas pasar yang ada (Puspitaet al., 2016).

Alasan untuk meningkatkan kualitas produk dapat ditunjukan untuk mempertahankan eksistensi suatu perusahaan bahkan agar dapat memenangkan persaingan bisnis.Salah satunya adalah persaingan pasar minuman isotonik di Indonesia.Penjualan minuman kemasan terus meningkat di Indonesia banyak bermunculan merek-merek baru. Tentu saja karena hal yang demikian persaingan akan semakin kian ketat dalam memasarkan produk, menghadapi hal tersebut banyak perusahaan yang memiliki strategi untuk menciptakan berbagai pilihan produk (merek) kepada konsumen, seperti mizone, pocari sweat, dan fatigon hydro. Mizone merupakan minuman isotonik bernutrisi yang hadir dalam 5 sensasi rasa unik: Lychee Lemon, Orange Lime, Apple Guava, Passion Fruit, dan Mangga Kweni. Minuman Mizone sebagai minuman kesehatan untuk mengganti cairan tubuh yang hilang akibat dari banyaknya aktivitas seseorang, sehingga Mizone hadir sebagai minuman ringan yang dapat memulihkan kondisi tubuh akibat kekurangan cairan menjadi lebih berenergi. Berikut ini disajikan beberapa jenis minuman isotonic berdasarkan top brand award 2018.

Tabel 1.

Indeks Merek Top Minuman Isotonik Tahun 2018

\begin{tabular}{lll}
\hline Merek & TBI (\%) & Top \\
\hline Pocari sweat & 63,4 & Top \\
Mizone & 26,2 & Top \\
Fatigon-hydro & 1,9 & \\
\hline
\end{tabular}

Sumber:www.topbrand-award.com, 2018

Tabel 1. menggambarkan hasil survetop brand award menunjukan bahwa produk minuman isotonik Pocari Sweat berada pada peringkat 1 (satu), dengan perolehan Top brand index sebesar 63,4 persen, selanjutnya Mizone berada di posisi kedua sebesar 26,2 persen, dan di susul oleh Fatigon Hydro sebesar 1,9 persen. Berdasarkan persaingan bisnis yang ketat tersebutperusahaan minuman isotonik tentunya harus menggunakan strategi yang tepat, agar konsumen tertarik untuk membeli produk yang ditawarkan untuk pertama kalinya, maupun untuk membeli ulang setelah sempat mengkonsumsi sebelumnya. 
Menurut Thakur \& Singh(2012)niat beli adalah niat individu untuk membeli merek tertentu yang ingin dibeli dan merek tersebut telah dievaluasi sehingga berguna bagi diri mereka. Tariq et al.(2013) menyatakan sangat penting menentukan barang yang tepat tentang apa yang konsumen butuhkan karena akan berpengaruh positif dengan niat beli ulang pelanggan.MenurutAli $(2013 ; 173)$ niat beli merupakan kecenderungankonsumen untuk membeli suatu merek atau mengambil tindakan yangberhubungan dengan pembelian yang diukur dengan tingkat kemungkinankonsumen melakukan pembelian untuk memprediksi perilaku konsumen diwaktu yang akan datang.Faktor yang membuat konsumen berniat untuk membeli ulang salah satunya adalah brand image, karena brand image mencerminkan tentang suatu produk. Sehingga semakin baik dan positif sebuah brand image maka akan berdampak pada minat beli ulang oleh konsumen. Image yang kuat serta positif memberikan dampak yang signifikan dalam merebut hati pelanggan.

Menurut Schiffman \& Kanuk (2010), citra merek adalah persepsi yang bertahan lama, dan dibentuk melalui pengalaman, dan sifatnya relative konsisten. Menurut Roslina (2010) brand imagemerupakan petunjuk yang akan digunakan oleh konsumen untuk mengevaluasi produk ketika konsumen tidak memiliki pengetahuan yang cukup tentang suatu produk. Pembelian ulang di pengaruhi oleh faktor citra merek yang positif, karena dengan citra merek yang kuat dapat menyebabkan konsumen menjadi loyal (Andreani, 2012).Brand yang dikenal luas, suatu produk dapat menjadi penghalang atas masuknya pesaing.Brand menjadi instrumen yang penting dalam pemasaran.Kekuatan sebuah merek ditandai dengan kemampuannya untuk bertahan di masa yang sulit sekalipun. Ketahanan yang tinggi tidak akan berpengaruh banyak dalam masa seperti apapun.Brand image yang baik dapat diciptakan dengan cara menghasilkan suatu produk yang berkualitas. Kualitas Produk menurut Kotler $(2011 ; 17)$ adalah keseluruhan ciri serta sifat dari suatu produk atau pelayanan yang berpengaruh pada kemampuannya untuk memuaskan kebutuhan yang dinyatakan atau tersirat.

Jill $(2013 ; 11)$ menyatakan bahwa apabila perusahaan ingin mempertahankan keunggulan kompetitifnya dalam pasar, perusahaan harus mengerti aspek dimensi apa saja yang digunakan oleh konsumen untuk membedakan produk yang dijual perusahaan dengan produk pesaing. Selain berpengaruh terhadap brand image kualitas produk juga berpengaruh langsung terhadap niat beli ulang. Kualitas produk berperan penting dalam membentuk niat beli konsumen, produk harus memiliki tingkat kualitas tertentu karena produk dibuat untuk memenuhi selera konsumen. Strategi pemasaran yang tepat dan terencana dalam perusahaanyaitu dengan cara brand image yang baik dibenak konsumen dan kualitas produk yang berkualitas (Lasander, 2013).

Berdasarkan pada beberapa temuan dari penelitian sebelumnya tentang pengaruh brand image, kualitas produk, dan niat beli ulang dengan hasil yang berbeda. Hasil penelitian dari Afif \& Suryono (2017) menyatakan bahwa kualitas produk tidak berpengaruh signifikan terhadap niat beli ulang. Hasil yang sama yang dilakukan oleh Arfiani \& Herman (2015) mendapatkan hasil bahwa kualitas produk tidak berpengaruh signifikan terhadap niat beli ulang. Hasil ini bertolak belakang dengan penelitian Aryadhe \& Rastini (2016) yang menyatakan bahwa 
kualitas produk dan brand image memiliki pengaruh positif terhadap niat beli ulang.Hal ini sejalan dengan hasil penelitian Astiani (2014) bahwa kualitas produk berpengaruh signifikan terhadap niat beli ulang.Hal tersebut mengindikasikan tingginya tingkat kualitas produk mizone yang membuat kuatnya brand image di benak konsumen yang pada akhirnya menimbulkan niat konsumen untuk melakukan niat beli ulang produk mizone.

Tujuan penelitian untuk menjelaskan pengaruh kualitas produk mizone terhadap brand imagedi Kota Denpasar. Pengaruh kualitas produk, brand image mizone terhadap niat beli ulang di Kota Dvenpasar. Menjelaskan peran brand image memediasi pengaruh kualitas produk mizone terhadap niat beli di Kota Denpasar. Hasil penelitian ini nantinya diharapkan dapat memberikan kontribusi pada pengembangan studi mengenai pemasaran yang dapat digunakan sebagai acuan dalam penelitian selanjutnya yang berkaitan dengan brand image, kualitas produk, dan niat beli ulang. Hasil penelitian ini nantinya diharapkan mampu digunakan sebagai bahan pertimbangan dari pihak mizone dalam merumuskan kebijakan yang berkaitan dengan brand image, kualitas produk dan niat beli ulang sehingga dapat meningkatkan kinerja bisnisnya.

Kualitas Produk menurut Kotler $(2011 ; 17)$ adalah keseluruhan ciri serta sifat dari suatu produk atau pelayanan yang berpengaruh pada kemampuannya untuk memuaskan kebutuhan yang dinyatakan atau tersirat.Kotler \& Amstrong (2012;27) mendefinisikan produk sebagai sesuatu yang dapat ditawarkan ke dalam pasar untuk diperhatikan, dimiliki, dipakai atau dikonsumsi sehingga dapat memuaskan keinginan dan kebutuhan.Kualitas produk adalah suatu usaha untuk memenuhi atau melebihi harapan pelanggan, dimana produk tersebut memiliki kualitas yang sesuai dengan standar kualitas yang telah ditentukan oleh prusahaan.

Jill $(2013 ; 11)$ menyatakan bahwa apabila perusahaan ingin mempertahankan keunggulan kompetitifnya dalam pasar, perusahaan harus mengerti aspek dimensi apa saja yang digunakan oleh konsumen untuk membedakan produk yang dijual perusahaan dengan produk pesaing. Semakin tinggi kualitas produk, maka semakin tinggi keputusan konsumen untuk melakukan pembelian(Andrianto et al, 2013). Ehsani \& Hossein(2015), menyatakan bahwa kualitas produk adalah persepsi pelanggan terhadap keseluruhan kualitas atau keunggulan produk atau layanan, sehubungan dengan tujuannya, relatif terhadap alternatif.

Menurut Kusuma (2016) citra merek adalah suatu totalitas kesan yang berada dalam memori konsumen tentang persepsi kualitas dari suatu produk barang dan jasa.Image atau citra sendiri adalah suatu gambaran, penyerupaan kesan utama atau garis besar bahkan bayangan yang dimiliki oleh seseorang tentang suatu.Oleh karena itu citra atau image dapat dipertahankan. Hawkins and Mothersbaugh (2013) menyatakan citra merek adalah mengacu pada memori skematik dari sebuah merek. Ini mengandung interpretasi target pasar terhadap atribut produk, manfaat, situasi penggunaan, pengguna, dan karakteristik pembuatan pasar.

Rizan et al. (2012) mengemukakan bahwa brand image adalah anggapan tentang merek yang direfleksikan konsumen yang berpegang padaingatan konsumen. Menurut Shahrinaz et al. (2016) memposisikan merek dan menciptakan kesadaran merek dari produk yang dimaksudkan melibatkan banyak 
perencanaan dan pelaksanaan kampanye iklan yang akan membantu pelanggan dalam mengenali merek dan menciptakan loyalitas merek.

Menurut Ali $(2013 ; 173)$ minat beli merupakan kecenderungankonsumen untuk membeli suatu merek atau mengambil tindakan yangberhubungan dengan pembelian yang diukur dengan tingkat kemungkinankonsumen melakukan pembelian untuk memprediksi perilaku konsumen diwaktu yang akan datang.Niat beli ulang merupakan bagian dari perilaku pembelian konsumen di mana kesesuaian antara performa dari produk atau jasa yang ditawarkan perusahaan menghasilkan minat konsumen untuk mengkonsumsinya lagi di masa yang akan datang (Wijaya, 2015).

Ain \& Ririn (2015) menyatakan bahwa niat beli ulang merupakan tindakan pasca pembelian yang disebabkan oleh adanya kepuasan yang dirasakan konsumen atas produk yang telah dibeli atau dikonsumsi sebelumnya.Niat pembelian ulang merupakan suatu komitmen konsumen yang terbentuk setelah konsumen melakukan pembelian suatu produk atau jasa.Sundalangi et al.(2014) minat membeli ulang yang tinggi mencerminkan tingkat kepuasan yang tinggi dari konsumen ketika memutuskan untuk mengkonsumsi produk yang diberikan setelah mencoba produk tersebut dan kemudian timbul rasa suka atau tidak suka terhadap produk. Menurut Hellier et al. (2003) dalam Yaqian (2011) niat beli ulang didefinisikan sebagai penilaian individu tentang membeli lagi layanan yang ditunjuk di perusahaan yang sama, dengan mempertimbangkan situasinya saat ini dan keadaan yang memungkinkan.

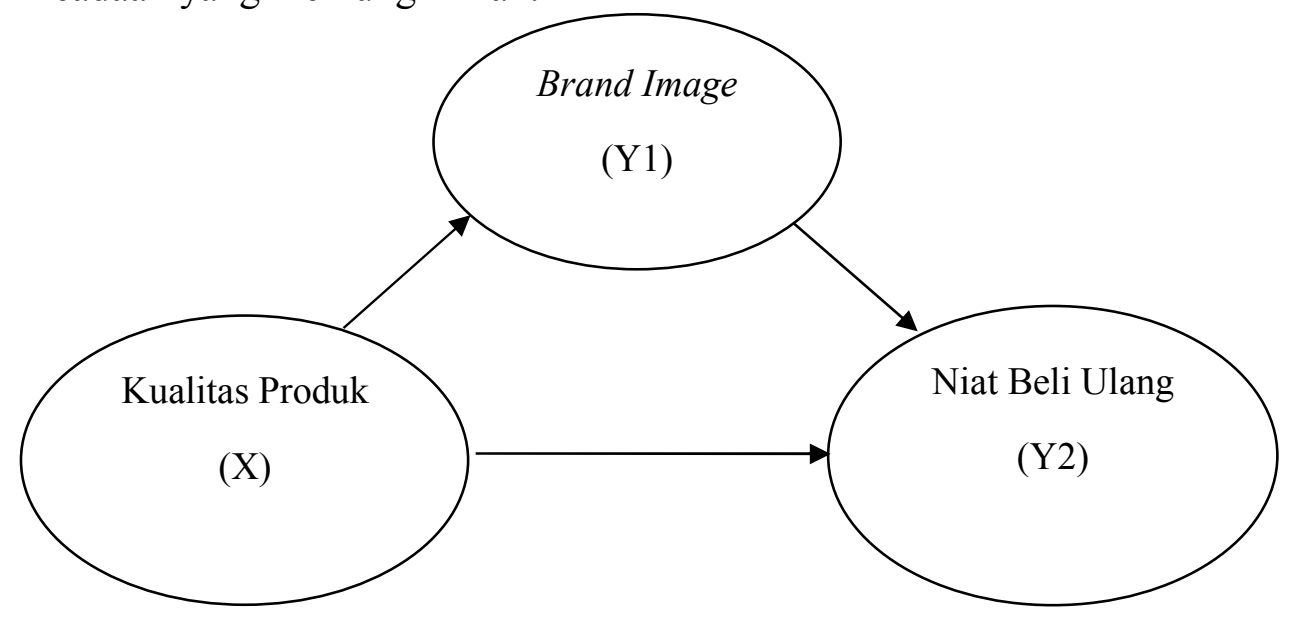

Gambar 1. Kerangka Penelitian

Jakpar et al. (2012) mengemukakan beberapa elemen yang dapat mengukur suatu kualitas produk, yaitu daya tahan (durability), kenyamanan (conformance), kehandalan (reliability), dan kemudahan perawatan (serviceability). Konsumen akan menilai suatu produk berkualitas tinggi apabila memiliki elemen-elemen ini dan tentunya ini dapat menunjukkan kemampuannya memenuhi kebutuhan konsumen dan sesuai dengan ekspektasi mereka terhadap produk. Kualitas suatu produk dapat mempengaruhi konsumen dalam pembentukan citra sebuah merek. Apabila kualitas produk sebuah merek yang dijual tinggi, maka konsumen akan 
mengasosiasikan kualitas produk yang tinggi pada merek tersebut, yang berarti citra merek tersebut adalah baik.

Penelitian yang dilakukan oleh Megarita et al. (2014) menemukan bahwa citra merek yang baik dapat tercipta dari peningkatan kualitas produk baik dari segi pengemasan produk dan peningkatan kualitas produk itu sendiri. Kemudian Wahid (2016) membuktikan pengaruh positif dan signifikan kualitas produk terhadap citra merek, yaitu konsumen akan memandang citra suatu merek itu baik apabila kualitas produk merek tersebut tinggi.

Studi yang dlakukan oleh Mufarrih(2015) juga menemukan bahwa kualitas produk yang tinggi berkaitan dengan kemampuan produk memenuhi kebutuhan psikologis dan fisik konsumen dengan maksimal, sehingga akanmembuat citra merek produk tersebut baik di mata konsumennya. Temuan mengenai hubungan kualitas produk dan citra merek juga dikemukakan oleh Nuraini (2015) yang menjelaskan bahwa kualitas produk yang tinggi mencerminkan citra merek yang baik, terutama untuk merek yang memasarkan produk barang, konsumen akan menilai baik buruknya citra merek dari atribut - atribut produk tersebut terutama kualitasnya.Berdasarkan telaah dan kajian penelitian terdahulu, maka dapat disusun hipotesis sebagai berikut.

$\mathrm{H}_{1}$ : Kualitas produk berpengaruh positif dan signifikan terhadap brand image

Menurut Kotler \& Amstrong(2012;347) kualitas produk adalah kemampuan suatu produk untuk melakukan fungsi-fungsinya, kemampuan ini meliputi daya tahan, kehandalan, ketelitian yang dihasilkan, kemudahan dioperasikan dan diperbaiki, dan atribut lain yang berharga pada produk secara keseluruhan. Menurut American Society for Quality Control (Lupiyoadi, 2001), kualitas adalah keseluruhan ciri-ciri dan karakteristik-karakteristik dari suatu barang atau jasa, dalam hal kemampuan untuk memenuhi kebutuhan-kebutuhan yang telah ditentukan.

Penelitian sebelumnya yang berjudul "Analisis Pengaruh Kualitas Pelayanan, kualitas produk dan promosi penjualan terhadap minat beli ulang (Studi pada konsumenbuket coffee dan Jazz)" oleh Triastuti(2012)menunjukkan adanya pengaruh positif variabel kualitas produk terhadap niatbeli ulang. Penelitian lain juga dilakukan Rizan et al.(2012) yang menunjukkan bahwa kualitas produk berpengaruh positif dan signifikan terhadap minat beli ulang.Hasil penelitian bahwa bahwa kualitas produk memiliki pengaruh yang paling besar, kualitas produk semakin terjaga dan ditingkatkan maka akan terciptanya minat beli ulang yang tinggi.Berdasarkan telaah dan kajian penelitian terdahulu, maka dapat disusun hipotesis sebagai berikut.

$\mathrm{H}_{2}$ : Kualitas produk berpengaruh positif dan signifikan terhadap niat beliulang Rangkuti $(2005 ; 2)$ mengatakan merek merupakan janji pemasar untuk secara konsisten memberikan fitur, manfaat, dan jasa tertentu kepada pembeli. Tariq et al. (2013) citra merek adalah aspek yang sangat penting terhadap niat pembelian. Ini membantu konsumen untuk memutuskan apakah merek yang dipilih adalah pilihan yang lebih baik bagi mereka dan mereka dipaksa untuk membuat niat pembelian beberapa kali.Sebuah citra yang baik membantu untuk menciptakan hubungan jangka panjang antara produk dan pengguna akhir. 
Berdasarkan Penelitian yang dilakukan Wijaya (2015) juga menunjukkan bahwa sikap positif konsumen terhadap suatu merek dapat meningkatkan niat beli ulang konsumen atau produk tersebut.Hal ini terjadi ketika konsumen merasa puas terhadap produk/jasa yang di terima dari suatu perusahaan penyedia barang/jasa tersebut maka sangat besar kemungkinan bagi konsumen untuk melakukan pembelian ulang.Berdasarkan telaah dan kajian penelitian terdahulu, maka dapat disusun hipotesis sebagai berikut.

$\mathrm{H}_{3}$ : $\quad$ Brand image berpengaruh positif dan signifikan terhadap niat beli ulang

Berdasarkan penelitian yang dilakukan oleh Anggitan(2013) menunjukan bahwa kualitas produk memiliki pengaruh positif langsung dengan niat beli ulang baik secara tidak langsung melalui brand image.Vazquez-Carrasco and Foxall dalam Thakur \& Singh (2012) juga menyatakan bahwa diantara variabel yang digunakan untuk mengukur adanya pengaruh terhadap niat beli ulang pada suatu produk, salah satunya menggunakan variabel citra merek.Penelitian tersebut membuktikan terdapat hubungan positif antara citra merek dengan niat beli ulang.

Menurut Saraswati (2014) citra merekberpengaruh nyata terhadap pembelian ulang.Hal tersebut serupa dengan hasil uji penelitian yang dilakukakan oleh Andriadi \& Nindria (2013) bahwa citra merek pada salah satu dimensinya memiliki pengaruh yang signifikan yang dapat membentuk niat beli ulang konnsumen. Aryadhe \& Rastini (2016) dalam hasil penelitiannya menemukan bahwa kualitas produk melalui brand image berpengaruh secara positif dan signifikan terhadap niat beli ulang.Berdasarkan telaah dan kajian penelitian terdahulu, maka dapat disusun hipotesis sebagai berikut.

$\mathrm{H}_{4}$ : $\quad$ Brand image berperan positif memediasi pengaruh kualitas produk terhadap niat beli ulang

\section{METODE PENELITIAN}

Lokasi penelitian ini dilakukan di Kota Denpasar, karena merupakan pusat perekonomian di Bali dan juga memiliki pertumbuhan penduduk yang padat yaitu dengan jumlah data pencatatan tahun terakhir yaitu 2016 sebanyak 880.300 jiwa yang dimana kebutuhan penduduknya semakin meningkat (www.bps.go.id, diakses pada 23 April 2018). Objek di dalam penelitian ini adalah pengaruh kualitas produk $(\mathrm{X})$ terhadap brand image $(M)$, pengaruh kualitas produk (X) terhadap niat beli ulang $(\mathrm{Y})$, pengaruh brand image $(\mathrm{M})$ terhadap niat beli ulang (Y), pengaruh brand image (M) Memediasi kualitas produk (X) dan niat beliulang (Y).

Populasi dalam penelitian ini adalah para konsumen di Kota Denpasar.yang sudah pernah membeli atau mengkonsumsi produk minuman isotonic mizone.Jumlah sampel yang digunakan dari kuisioner ke responden yaitu sebanyak 12 indikator sehingga dengan menggunakan estimasi berdasarkan jumlah parameter diperoleh ukuran sampel sebesar 60 sampai 120 responden jumlah responden yang diambil sebagai sampel adalah sebanyak 12 X $10=120$ responden. Jadi, responden yang diambil sebanyak 120 orang responden. 
Tabel 2.

Identifikasi Variabel Penelitian

\begin{tabular}{|c|c|c|c|c|}
\hline No & $\begin{array}{l}\text { Klasifikasi } \\
\text { Konstruk }\end{array}$ & Konstruk & Indikator & Sumber \\
\hline 1 & $\begin{array}{l}\text { Variabel } \\
\text { Eksogen } \\
\text { (X) }\end{array}$ & $\begin{array}{l}\text { Kualitas } \\
\text { Produk }\end{array}$ & $\begin{array}{ll}\text { 1. } & \text { Performance(kinerja) } \\
\text { 2. } & \text { Reliability (kehandalan) } \\
\text { 3. } & \text { Durability (daya tahan) } \\
\text { 4. } & \text { Confermance. (standar) } \\
\text { 5. } & \text { Design (desain) }\end{array}$ & $\begin{array}{l}\text { Dimyati (2004:78- } \\
80)\end{array}$ \\
\hline 2. & $\begin{array}{c}\text { Variabel } \\
\text { Mediasi (M) }\end{array}$ & $\begin{array}{l}\text { Brand } \\
\text { Image }\end{array}$ & $\begin{array}{l}\text { 1. Pengakuan terhadap merek } \\
\text { 2. Reputasi yang baik } \\
\text { 3. Hubungan antara merek dengan } \\
\text { konsumen }\end{array}$ & Ananda (2011:10) \\
\hline 3. & $\begin{array}{c}\text { Variabel } \\
\text { Endogen (Y) }\end{array}$ & $\begin{array}{l}\text { Niat Beli } \\
\text { Ulang }\end{array}$ & $\begin{array}{l}\text { 1. Penggunaan ulang produk } \\
\text { 2. Pembelian produk } \\
\text { 3. Rekomendasi produk } \\
\text { 4. Antisipasi produk }\end{array}$ & $\begin{array}{lr}\text { Chaudhuri } & \text { and } \\
\text { Ligas (2009) } & \text { serta } \\
\text { Chinhor and } & \text { and } \\
\text { Watcharee (2014) }\end{array}$ \\
\hline
\end{tabular}

Sumber: Data diolah, 2018

Teknik analisis data yang digunakan dalam peneliatan ini adalah analisis jalur. Persamaan analisis jalur dalam penelitian ini yaitu:

Persamaan Sub-Struktural 1

$$
\mathrm{Y}_{1}=\beta_{1} \mathrm{X}+\mathrm{e} 1
$$

Persamaan Sub-Struktural 2

$$
\mathrm{Y}_{2}=\beta_{2} \mathrm{X}+\beta_{3} \mathrm{Y} 1+\mathrm{e}_{2} . .
$$

Keterangan :

$$
\begin{array}{ll}
\mathrm{X} & =\text { kualitas produk } \\
\mathrm{M} & =\text { brand image } \\
\mathrm{Y} & =\text { niat beli ulang } \\
\beta_{1}, \beta_{2}, \beta_{3} & =\text { koefisien regresi variabel } \\
\mathrm{e} & =\text { error }
\end{array}
$$

\section{HASIL DAN PEMBAHASAN}

Objek dalam penelitian ini adalah responden yang mengetahui dan mengonsumsi produk minuman isotonic mizone dan sampel yang di tarik berjumlah 120 responden dengan teknik purposive sampling.

Data untuk profil responden di Denpasar didapatkan dari kuesioner yang telah disebarkan. Jumlah responden yang berjenis kelamin laki-laki diperoleh sebanyak 79 orang (65,8 persen) sedangkan yang berjenis kelamin perempuan diperoleh sebanyak 41 orang (34,2 persen) sehingga jumlah responden yang didapatkan sebanyak 120 orang. Dari 120 orang, responden dengan kisaran umur 17-21 tahun berjumlah 20 orang (16,7 persen), 22-26 tahun berjumlah 21 orang (17,5 persen), 27-31 tahun berjumlah 31orang (25,8 persen), 32-36 tahun berjumlah 23 orang (19,2 persen), 37-41 tahun berjumlah 21 orang (17,5 persen) dan $>42$ tahun berjumlah 4 orang (3,3 persen). Kisaran umur tertinggi adalah 27 sampai 31 tahun. 
Tabel 3.

Karakteristik Responden

\begin{tabular}{|c|c|c|c|c|}
\hline No & Variabel & Klasifikasi & Jumlah & Persen \\
\hline \multirow[t]{6}{*}{1} & Usia & 17-21 Tahun & 21 & $17,5 \%$ \\
\hline & & 27-31 Tahun & 31 & $25,8 \%$ \\
\hline & & 32-36 Tahun & 23 & $19,2 \%$ \\
\hline & & 37-41 Tahun & 21 & $17,5 \%$ \\
\hline & & $>42 \quad$ Tahun & 4 & $3,3 \%$ \\
\hline & & Jumlah & 120 & $100 \%$ \\
\hline \multirow[t]{3}{*}{2} & Jenis Kelamin & Pria & 79 & $65,8 \%$ \\
\hline & & Wanita & 41 & $34,2 \%$ \\
\hline & & Jumlah & 120 & $100 \%$ \\
\hline \multirow[t]{6}{*}{3} & Pendidikan Terakhir & SMA Sederajat & 24 & $20 \%$ \\
\hline & & Diploma & 22 & $18,3 \%$ \\
\hline & & $\mathrm{S} 1$ & 47 & $39,2 \%$ \\
\hline & & S2 & 23 & $19,2 \%$ \\
\hline & & S3 & 4 & $3,3 \%$ \\
\hline & & Jumlah & 120 & $100 \%$ \\
\hline \multirow[t]{6}{*}{4} & Pekerjaan & Karyawan Swasta & 26 & $21,7 \%$ \\
\hline & & Pelajar/Mahasiswa & 23 & $19,2 \%$ \\
\hline & & Pengusaha & 24 & $20 \%$ \\
\hline & & PNS & 21 & $17,5 \%$ \\
\hline & & TNI/POLRI & 26 & $21,7 \%$ \\
\hline & & Jumlah & 120 & $100 \%$ \\
\hline
\end{tabular}

Sumber : Data diolah, 2018

Menurut pekerjaan, sebanyak 26 orang $(21,7$ persen) bekerja sebagai karyawanswasta, 23 orang (19,2 persen) adalah sebagai pelajar/ mahasiswa, 24 orang (20 persen) bekerja sebagai pengusaha, 21 orang (17,5 persen) bekerja sebagai PNS, dan 26 orang (21,7 persen) bekerja sebagai TNI/POLRI.

Menurut pendidikannya, sebanyak 22 orang (18,3 persen) merupakan lulusan Diploma, 47 orang (39,2 persen) merupakan lulusan S1, 23 orang (19,2 persen) merupakan lulusan S2, 4 orang (3,3\%) merupakanlulusan S3, dan 24 orang (20 persen) merupakan lulusan dari SMA/sederajat.

Validitas menunjukkan tingkat ketepatan antara data yang diteliti oleh peneliti dengan data yang sesungguhnya. Uji validitas dapat dilakukan dengan mengkorelasikan antara skor item insrumen dengan skor total seluruh item pertanyaan. Jika korelasi antara masing-masing skor butir pernyataan terhadap pernyataan menunjukkan nilai koefisien korelasinya lebih dari 0,30 $(r>0,3)$ maka masing-masing butir pernyataan tersebut dikatakan valid.

Hasil uji validitas pada Tabel 4. menunjukkan bahwa nilai koefisien korelasi dari masing-masing indikator menunjukkan nilai yang lebih besar dari 0,3 $(\mathrm{r} \geq 0,30)$, hal ini berarti bahwa semua instrumen yang digunakan adalah valid. Hasil uji validitas dari variabel-variabel yang diuji dapat dilihat pada Tabel 4.di bawah ini.

Reliabilitas menunjukan sejauh mana suatu alat pengukuran dapat dipercaya atau dapat diandalkan. Apabila suatu alat ukur dipakai dua kali untuk mengukur gejala yang sama dan hasil pengukuran yang diperoleh relative konsisten, maka alat pengukur tersebut reliabel. Suatu instrumen dikatakan reliabel, jika instrumen 
tersebut memiliki nilai Alpha Cronbach lebih dari 0,60. Adapun hasil dari uji reliabilitas dapat ditunjukkan pada Tabel 5. berikut :

Tabel 4.

Uji Validitas

\begin{tabular}{|c|c|c|c|}
\hline Variabel & Instrumen & Pearson Correlation & Keterangan \\
\hline Kualitas Produk & $\mathrm{X} .1$ & 0,731 & Valid \\
\hline \multirow[t]{4}{*}{$(\mathrm{X})$} & X.2 & 0,870 & Valid \\
\hline & X.3 & 0,724 & Valid \\
\hline & X.4 & 0,859 & Valid \\
\hline & X.5 & 0,907 & Valid \\
\hline \multirow[t]{3}{*}{ Brand Image (M) } & M.1 & 0,832 & Valid \\
\hline & M.2 & 0,752 & Valid \\
\hline & M.3 & 0,801 & Valid \\
\hline \multirow{4}{*}{$\begin{array}{l}\text { Niat Beli Ulang } \\
\text { (Y) }\end{array}$} & Y.1 & 0,751 & Valid \\
\hline & Y.2 & 0,826 & Valid \\
\hline & Y.3 & 0,882 & Valid \\
\hline & Y.4 & 0,749 & Valid \\
\hline
\end{tabular}

Sumber: Data diolah, 2018

Tabel 5.

Uji Reliabilitas

\begin{tabular}{ccc}
\hline Variabel & Cronbach's Alpha & Keterangan \\
\hline Kualitas Produk $(\mathrm{X})$ & 0,878 & Reliabel \\
Brand Image $(\mathrm{M})$ & 0,710 & Reliabel \\
Niat Beli Ulang $(\mathrm{Y})$ & 0,816 & Reliabel \\
\hline
\end{tabular}

Sumber : Data diolah, 2018

Hasil uji reliabilitas yang disajikan dalam Tabel 5. menunjukkan bahwa ketiga instrumen penelitian yaitu memiliki koefisien Cronbach's Alpha lebih dari 0,60. Hal ini dapat dikatakan bahwa semua instrumen reliabel sehingga dapat digunakan untuk melakukan penelitian.

Penelitian ini melakukan uji asumsi klasik dengan tujuan untuk memastikan hasil yang diperoleh dapat memenuhi asumsi dasar dalam analisis regresi. Hasil uji asumsi klasik yang dilakukan adalah uji normalitas, uji multikoliniearitas dan uji heterokedasitas. Persamaan regresi 1 akan menggambarkan pengaruh kualitas produk terhadap niat beli ulang, sedangkan persamaan regresi 2 menggambarkan pengaruh kualitas produk dan brand image terhadap niat beli ulang. Program SPSS version 22 for windows digunakan untuk membantu pengujian uji asumsi klasik di dalam penelitian ini. Hasil Analisis Jalur Persamaan Regresi 1 adalah sebagai berikut:

$$
\begin{aligned}
& \hat{\mathrm{Y}}=4,078-0,398 \mathrm{X}_{1} \\
& \mathrm{~S}(\beta)=(0,749)(0,037) \\
& \mathrm{t} \quad=(5,444)(10,762) \\
& \mathrm{Sig}=(0,000)(0,000) \\
& \mathrm{R}^{2}=0,495 \mathrm{df}=118 \quad \mathrm{~F}=115,811 \quad \mathrm{Sig}=0,000
\end{aligned}
$$

Hasil Analisis Jalur Persamaan Regresi 2 adalah sebagai berikut: 


$$
\begin{aligned}
& \hat{Y}=-1,350-0,174 X_{1}+1,113 X_{2} \\
& S(\beta)=(0,604)(0,037)(0,066) \\
& t \quad=(-2,235)(4,650)(16,768) \\
& \text { Sig }=(0,027)(0,000)(0,000) \\
& R^{2}=0,875 \text { df }=117 \quad \text { F }=408,709 \quad \text { Sig }=0,000
\end{aligned}
$$

Uji ini bertujuan untuk mengetahui apakah residual dari model regresi yang dibuat berdistribusi normal atau tidak. Untuk menguji apakah data yang digunakan normal atau tidak dapat dilakukan dengan menggunakan uji Kolmogorov Sminarnov. Apabila koefisien Asymp.Sig. (2-tailed) lebih besar dari 0,05 maka data tersebut dikatakan berdistribusi normal.

Tabel 6.

Hasil Uji Normalitas Persamaan Regresi 1

\begin{tabular}{cc}
\hline & Unstandardized Residual \\
\hline $\mathrm{N}$ & 120 \\
Kolmogorov-Smirnov $Z$ & 1,280 \\
Asymp.Sig.(2-tailed) & 0,076 \\
\hline
\end{tabular}

Sumber:Data diolah, 2018

Berdasarkan Tabel 6. dapat dilihat bahwa nilai Kolmogorov Smirnov (K-S) sebesar 1,280, sedangkan nilai Asymp.Sig. (2-tailed) sebesar 0,076. Hasil tersebut mengindikasikan bahwa model persamaan regresi tersebut berdistribusi normal karena nilai Asymp.Sig.(2-tailed) 0,076 lebih besar dari nilai alpha 0,05.

Tabel 7.

Hasil Uji Normalitas Persamaan Regresi 2

\begin{tabular}{ll}
\hline & Unstandardized Residual \\
\hline $\mathrm{N}$ & 120 \\
Kolmogorov-Smirnov $Z$ & 1,084 \\
Asymp.Sig.(2-tailed) & 0,190 \\
\hline Sumber: Data diolah, 2018 &
\end{tabular}

Berdasarkan Tabel 7. dapat dilihat bahwa nilai Kolmogorov Smirnov (K-S) sebesar 1,084, sedangkan nilai Asymp.Sig. (2-tailed) sebesar 0,190. Hasil tersebut mengindikasikan bahwa model persamaan regresi tersebut berdistribusi normal karena nilai Asymp.Sig.(2-tailed) 0,190 lebih besar dari nilai alpha 0,05. Adanya multikolinearitas dapat dilihat dari nilai tolerance atau variance inflation factor (VIF). Jika nilai tolerance lebih dari $10 \%$ atau VIF kurang dari 10, maka dikatakan tidak ada multikolinearitas.

Berdasarkan Tabel 8. dapat dilihat bahwa nilai tolerance dan VIF dari variabel Kualitas Produk dan Brand Image. Nilai tersebut menunjukkan bahwa nilai tolerance pada variabel kualitas produk lebih besar dari $10 \%$ dan nilai VIF lebih kecil dari 10 yang berarti bahwa model persamaan regresi 2 bebas dari multikolinearitas. 
Jika tidak ada satu pun variabel bebas yang berpengaruh signifikan terhadap nilai absolute residual atau nilai signifikansinya diatas 0,05 maka tidak mengandung gejala heteroskedastisitas.

Tabel 8.

Hasil Uji Multikolinearitas Persamaan Regresi 2

\begin{tabular}{ccc}
\hline Variabel & Tolerance & VIF \\
\hline Kualitas Produk & 0,505 & 1,981 \\
Brand Image & 0,505 & 1,981 \\
\hline
\end{tabular}

Sumber :Data diolah, 2018

Tabel 9.

Hasil Uji Heteroskedastisitas Persamaan Regresi 1

\begin{tabular}{cccc}
\hline Variabel bebas & B & t hitung & Sig. \\
\hline Kualitas Produk &,- 004 &,- 125 & 0,901
\end{tabular}

Pada Tabel 9. dapat dilihat bahwa nilai Sig. dari variabel kualitas produk sebesar 0,901 lebih besar dari 0,05 yang berarti tidak terdapat pengaruh variabel bebas terhadap absolute residual. Dengan demikian, model yang dibuat tidak mengandung gejala heteroskedastisitas.

Tabel 10.

Hasil Uji Heteroskedastisitas Persamaan Regresi 1

\begin{tabular}{cccc}
\hline Variabel bebas & B & $\mathbf{t}_{\text {hitung }}$ & Sig. \\
\hline Kualitas Produk &,- 013 &,- 522 & 0,603 \\
Brand Image &,- 038 &,- 844 & 0,400 \\
\hline
\end{tabular}

Sumber:Data diolah, 2018

Pada Tabel 10. dapat dilihat nahwa nilai Sig. Berdasarkan variabel Kualitas Produk dan Brand Image masing-masing sebesar sebesar 0,603 dan 0,400. Nilai tersebut lebih besar dari 0,05 yang berarti tidak terdapat pengaruh antara variabel bebas terhadap absolute residual. Dengan demikian, model yang dibuat tidak mengandung gejala heteroskedastisitas.

Perhitungan koefisien path dilakukan dengan analisis regresi melalui software SPSS 18.0 for Windows, diperoleh hasil yang ditunjukan nilai $\beta_{1}$ adalah sebesar 0,704 memiliki arti bahwa Kualitas Produk berpengaruh positif terhadap Brand Image, dengan kata lain jika Kualitas Produk meningkat maka akan mengakibatkan peningkatan pada Brand Image minuman isotonic Mizone sebesar 0,704 .

Berdasarkan hasil analisis jalur substruktur 2 yaitunilai $\beta_{2}$ adalah sebesar 0,214 memiliki arti bahwa kualitas produk berpengaruh positif terhadap niat beli ulang, dengan kata lain jika faktor kualitas produk meningkat maka akan mengakibatkan peningkatan pada niat beli ulang sepatu olahraga Adidas di Kota Denpasar sebesar 0,214.

Nilai $\beta_{3}$ adalah sebesar 0,772 memiliki arti bahwa brand image berpengaruh positif terhadap niat beli ulang, dengan kata lain jika brand image meningkat 
maka akan terjadi peningkatan niat beli ulang pada sepatu olahraga Adidas di Kota Denpasar sebesar 0,772.

Berdasarkan model substruktur 1 dan substruktur 2, maka dapat disusun model diagram jalur akhir. Sebelum menyusun model diagram jalur akhir, terlebih dahulu dihitung nilai standar eror sebagai berikut:

$$
\begin{aligned}
& \mathrm{Pe}_{\mathrm{i}}=\sqrt{1-\mathrm{R}_{\mathrm{i}}^{2}} \ldots \ldots \ldots \ldots \ldots \ldots \ldots \ldots \ldots \ldots \ldots \\
& \mathrm{Pe}_{1}=\sqrt{1-R_{1}^{2}}=\sqrt{1-0,495}=0,710 \\
& \mathrm{Pe}_{2}=\sqrt{1-R_{2}^{2}}=\sqrt{1-0,875}=0,353
\end{aligned}
$$

Berdasarkan perhitungan pengaruh error $\left(\mathrm{Pe}_{1}\right)$, didapatkan hasil pengaruh error $\left(\mathrm{Pe}_{1}\right)$ sebesar 0,710 dan pengaruh error $\left(\mathrm{Pe}_{2}\right)$ sebesar 0,353. Hasil koefisien

$$
\begin{aligned}
\mathrm{R}^{2} \mathrm{~m} & =1-\left(\mathrm{Pe}_{1}\right)^{2}\left(\mathrm{Pe}_{2}\right)^{2} \\
& =1-(0,710)^{2}(0,353)^{2} \\
& =1-(0,504)(0,125) \\
& =1-0,063=0,937
\end{aligned}
$$

Nilai determinasi total sebesar 0,937 mempunyai arti bahwa sebesar 93,7\% variasi niat beli ulangdipengaruhi oleh variasi kualitas produk dan brand image, sedangkan sisanya sebesar $6,3 \%$ dijelaskan oleh faktor lain yang tidak dimasukkan ke dalam model.

Berdasarkan hasil analisis pengaruh kualitas produk terhadap niat beli ulang diperoleh nilai Sig. $t$ sebesar 0,000 dengan nilai koefisien beta 0,214. Nilai Sig. $t$ $0,000<0,05$ mengindikasikan bahwa $\mathrm{H}_{0}$ ditolak dan $\mathrm{H}_{1}$ diterima. Hasil ini mempunyai arti bahwa kualitas produkberpengaruh positif dan signifikan terhadap niat beli ulang.

Berdasarkan hasil analisis pengaruh brand image terhadap niat beli ulangdiperoleh nilai Sig. $t$ sebesar 0,000 dengan nilai koefisien beta 0,704 . Nilai Sig. t $0,000<0,05$ mengindikasikan bahwa $\mathrm{H}_{0}$ ditolak dan $\mathrm{H}_{1}$ diterima. Hasil ini mempunyai arti bahwa brand image berpengaruh positif dan signifikan terhadap niat beli ulang. Perhitungan pengaruh antar variabel terdapat dalam Tabel 11 sebagai berikut.

Tabel 11.

Pengaruh Langsung dan Pengaruh Tidak Langsung serta Pengaruh Total Kualitas Produk (X), Brand Image ( $\left.\mathrm{Y}_{1}\right)$, dan Niat Beli Ulang( $\left.\mathrm{Y}_{2}\right)$

\begin{tabular}{llll}
\hline $\begin{array}{l}\text { Pengaruh } \\
\text { Variabel }\end{array}$ & $\begin{array}{c}\text { Pengaruh } \\
\text { Langsung }\end{array}$ & $\begin{array}{c}\text { Pengaruh Tidak Langsung Melalui Brand } \\
\text { Image } \\
(\mathbf{M})(\boldsymbol{\beta} \mathbf{1} \mathbf{x} \boldsymbol{\beta 3})\end{array}$ & Pengaruh Total \\
\hline $\mathrm{X}_{1} \rightarrow \mathrm{Y}_{1}$ & 0,704 & - & 0,704 \\
$\mathrm{X}_{1} \rightarrow \mathrm{Y}_{2}$ & 0,214 & 0,543 & 0,757 \\
$\mathrm{Y}_{1} \rightarrow \mathrm{Y}_{2}$ & 0,772 & - & 0,772 \\
\hline Sumber : Data diolah, 2018 &
\end{tabular}


Uji sobel merupakan alat analisis untuk menguji signifikansi dari hubungan tidak langsung antara variabel independen dengan variabel dependen yang dimediasi oleh variabel mediator. Uji Sobel dirumuskan dengan persamaan berikut dan dapat dihitung dengan menggunakan aplikasi Microsoft Excel 2007.Uji sobel dihitung dengan rumus dibawah ini:

$$
\begin{aligned}
& Z=\frac{\mathrm{ab}}{\sqrt{\mathrm{b}^{2} s_{a}^{2}+a^{2} s_{b}^{2}+s_{a}^{2} s_{b}^{2}}} \\
& \operatorname{Sig}=(1-\operatorname{NORMDIST}(Z))+2))
\end{aligned}
$$

Keterangan:

$$
\begin{aligned}
\mathrm{a} & =0,704 \\
\mathrm{~S} \mathrm{a} & =0,037 \\
\mathrm{~b} & =0,772 \\
\mathrm{Sb} & =0,066 \\
Z & =\frac{0,704.0,772}{\sqrt{0,772^{2} 0,704^{2}+0,704^{2} 0,066^{2}+0,037^{2} 0,066^{2}}} \\
& \quad Z=\frac{0,5435}{\sqrt{0,0022+0,0008+0,0000}} \\
Z & \quad Z=\frac{0,5435}{0,0030} \\
Z &
\end{aligned}
$$

Hasil dari pengujian variabel mediasi yaitu brand image didapatkan Z hitung sebesar 9,9546>1,96 dengan tingkat signifikan sebesar $0,000<0,05$ yang berarti $\mathrm{H}_{0}$ ditolak dan $\mathrm{H}_{1}$ diterima yang berarti variabel brand image dinilai secara signifikan memediasi variabel kualitas produk pada niat beli ulang pada minuman isotonic mizone di Kota Denpasar.

Pengujian hipotesis pada pengaruh kualitas produk terhadap brand image menunjukkan bahwa kualitas produk secara signifikan berpengaruh positif terhadap brand image. Ini berarti semakin baik kualitas produk yang diberikan oleh minuman isotonic Mizone maka akan meningkatkan brand image dari minuman isotonic Mizone.

Hasil penelitian ini mendukung temuan dari (Noerchoidah, 2013). Laura \& Ringo (2017), menyatakan bahwa kualitas produk mempengaruhi secara positif signifikan terhadap brand image. Pengujian hipotesis pada pengaruh kualitas produk terhadap niat beli ulang menunjukkan bahwa kualitas produk berpengaruh secara signifikan positif terhadap niat beli ulang. Ini berarti semakin baiknya kualitas produk yang diberikan oleh minuman isotonic Mizone, maka akan meningkatkan niat beli ulang konsumen pada minuman isotonic Mizone. Hasil penelitian ini mendukung temuan dari penelitian terdahuluAstiani (2014), yang menunjukkan bahwa kualitas produk berpengaruh positif dan signifikan terhadap ninat beli ulang. 
Pengujian hipotesis pada pengaruh brand imageterhadap niat beli ulang menunjukkan bahwa brand imagesecara signifikan berpengaruh positif terhadap niat beli ulang. Ini berarti semakin baiknya brand imageyang diberikan oleh minuman isotonic Mizone, maka akan meningkatkan niat beli ulang pada minuman isotonic Mizone di Kota Denpasar. Hasil penelitian ini mendukung temuan dari penelitian terdahulu Astiani (2014), yang menunjukkan bahwa kualitas produk berpengaruh positif dan signifikan terhadap ninat beli ulang.

Pengujian hipotesis pada peran brand image dalam memediasi kualitas produk terhadap niat beli ulang menunjukkan bahwa brand image mampu memediasi pengaruh kualitas produk terhadap niat beli ulang. Ini berarti brand image memediasi pengaruh kualitas produk terhadap niat beli ulang secara parsial. Dengan kata lain, brand image memperkuat pengaruh kualitas produk terhadap niat beli ulang. Hasil penelitian ini mendukung temuan dari Aryadhe \& Rastini, (2016), Astiani (2014) yakni kualitas produk melalui brand image berpengaruh secara positif dan signifikan terhadap niat beli ulang.

Implikasi dari penelitian ini mencakup dua hal yaitu, implikasi teoritis dan implikasi praktis yang menekankan pada manfaat nyata dari hasil penelitian ini untuk meningkatkan pelanggan pada produk sepatu olahraga Adidas. Perusahaan sebaiknya mempertahankan brand imageyang baik melalui kualitas produk yang baik sehingga pelanggan mempunyai niat untuk membeli kembali produk minuman isotonic Mizone. Beberapa implikasi hasil penelitian ini adalah sebagai berikut: faktor yang berhubungan dengan niat beli ulang dalam peneltian ini adalah kualitas produk dan brand image. Implikasi teoritis yang berkaitan dengan niat beli ulang secara konsisten memperkuat teori sebelumnya bahwa kualitas produk dan brand image memengaruhi pelanggan terhadap timbulnya niat untuk membeli ulang. Selain itu, variabel brand image mampu menjadi pemediasi kualitas produk dengan niat beli ulang.

Semakin baik kualitas produk yang dimiliki produk sepatu olahraga Adidas maka akan dapat meningkatkan brand image yang baik dan brand image tersebut memiliki peranan penting dalam mempengaruhi niat pada pembelian ulang terhadap minuman isotonic Mizone. Hal ini mendukung penelitian yang telah diungkapkan pada hipotesis penelitian, sehingga dapat disimpulkan bahwa penelitian ini mendukung serta memperjelas hubungan antara variabel brand image, kualitas produk, dan niat beli ulang.

Hasil dari penyebaran kuesioner secara spesifik yang ditunjukkan dalam pernyataan responden tentang kualitas produk, brand image dan niat beli ulang bahwa mereka rata-rata setuju pada pernyataan mengenai kualitas produk, brand image dan niat beli ulang, maka dengan begitu dapat disimpulkan bahwa pernyataan tersebut dapat merefleksikan perilaku pembelian konsumen yang berarti bahwa responden memiliki kecenderungan melakukan pembalian ulang terhadap minuman isotonic Mizone di Kota Denpasar.

Patut disadari bahwa terdapat beberapa keterbatasan dari penelitian ini yang diantaranya penelitian ini hanya dilakukan dalam titik waktu tertentu, sedangkan lingkungan setiap saat dapat berubah, yang menyebabkan penelitian ini penting untuk dilakukan kembali pada masa yang mendatang.Kurangnya variabel, di 
mana masih ada variabel-variabel lain yang dapat mempengaruhi niat beli ulang seperti, citra toko, dan promosi penjualan.

\section{SIMPULAN}

Kualitas produk berpengaruh positif dan signifikan terhadap brand imagedengandiperoleh t-hitung sebesar 10,762 dan nilai signifikansinya 0,000.Kualitas produk berpengaruh positif dan signifikan terhadap niat beli ulangdengant-hitung sebesar 12,607 dan nilai signifikansinya 0,000. Brand image berpengaruh positif dan signifikan terhadap niat beli ulangdengandiperoleh $t$ hitung sebesar 16,768 dan nilai signifikansinya 0,000.Brand image berperan positif memediasi pengaruh kualitas produk terhadap niat beli ulangdanhasil uji Sobel Test yang telah dilakukan diperoleh bahwa nilai Z sebesar 9,95>1.98 dengan tingkat signifikansi 5\%.

Pihak produsen Mizone diharapkan agar lebih bisa meningkatkan dan mempertahankanbrand image agar Mizone memiliki image yang positif, karena brand image mampu menarik minat konsumen untuk membeli suatu produk. Kualitas ketahanan produk Adidas perlu diperbaiki meski produk yang dihasilkan sudah cukup baik agar niat konsumen untuk membeli ulang semakin meningkat.

Bagi peneliti selanjutnya, diharapkan untuk melakukan penelitian secara spesifik pada rasa minuman isotonic Mizone. Dalam penelitian ini di masa mendatang juga perlu untuk menggunakan variabel-variabel yang lain seperti citra toko, dan promosi penjualan, sehingga dapat memperkaya informasi yang diperoleh.

\section{REFERENSI}

Afif, G. R., \& Suryono, B. S. (2017). Analisis Pengaruh Kualitas Produk, Kualitas Pelayanan, dan Citra Merek Terhadap Minat beli Ulang Pada Sepatu Nike Running di Semarang Melalui Kepuasan Pelanggan Sebagai Variabel Intervening. Diponogoro Journal Of Management. Semarang: Universitas Diponogoro, 6(1), 1-12.

Ain, \& Ririn. (2015). Pengaruh Citra Merek Melalui Sikap Konsumen Terhadap Niat Beli Ulang Pada Produk Busana Muslim Zoya Di Surabaya. JESTT, 2(7).

Ali, H. (2013). Marketing Cetakan Pertama. Yogyakarta: Media Pressindo.

Andreani. (2012). The Impact of Brand Image Towards Loyalty with Satisfaction as A Mediator in McDonald's. Jurnal Manajemen Dan Kewirausahaan.

Andriadi, A., \& Nindria. (2013). Pengaruh Persepsi Kualitas Layanan dan Citra Merek Telkom Flexi Terhadap Niat Beli Ulang. Jurnal Ilmu Manajemen, $1(2)$.

Andrianto, Noky, H., \& Idris. (2013). Pengaruh Kualitas Produk, Citra Merek, Harga, dan Promosi Terhadap Keputusan Pembelian Mobil Jenis MPV 
Merek Toyota Kijang Innova di Semarang. Diponegoro Journal Of Management, 2(3).

Anggitan, R. (2013). No TitleAnalisis Pengaruh Kualitas Produk, Harga dan Promosi Terhadap Loyalitas Pelanggan Dengan Minat Beli Ulang Sebagai variabel Intervening (Studi Pada Shibuya Resto Citraland Mall Semarang). Jurnal Manajemen.

Arfiani, \& Herman. (2015). Pengaruh Kualitas Produk Dan Kualitas Pelayanan Terhadap Kepuasan Konsumen Dan Minat Beli Ulang. Sekolah Tinggi Ilmu Ekonomi Bongaya Makassar, 3, 14-34.

Aryadhe, P., \& Rastini, N. M. (2016). Kualitas Pelayanan, Kualitas Produk dan Citra Merek Terhadap Niat Beli Ulang Di PT. Agung Toyota Denpasar. EJurnal Manajemen Unud., 5(9).

Astiani, Y. (2014). Pengaruh Kualitas Produk, Lokasi dan Lingkungan Fisik Terhadap Pembelian Ulang Pada Warung Kopi Harapan J2 di Kota Palu. EJurnal Katalogis, 2(7).

Ehsani, Z., \& Hossein, M. (2015). Effect of quality and price on customer satisfaction and commitment in Iran auto industry. International Journal of Service Science, Management and Engineering, 1(5).

Fouladivanda, F., Pashandi, M., Hooman, A., \& Khanmohammadi, Z. (2013). The effect of Brand Equity on Consumer Buying Behavior in term of FMCG in Iran. Interdisciplinary Journal of Contemporary Research In Business, 945957.

Hawkins, \& Mothersbaugh. (2013). Consumer Behavior: Building Marketing Strategy 12e. New York: McGraw-Hill Companies, Inc.

Hellier, P. K., Geursen., G. M., Carr, R. A., \& Rickard, J. A. (2003). Customer RepurchaseIntention: A General Structural Equation Model. Journal of Marketing, 37.

Jakpar, S., Na, A. G. S., \& Johari, A. (2012). Examining the Product Quality Attributes That Influences Customer Satisfaction Most When the Price Was Discounted: A Case Study in Kuching Sarawak. International Journal of Business and Social Science.

Jill. (2013). Menumbuhkan dan mempertahankan kesetiaan pelanggan. Jakarta: Erlangga.

Kotler, \& Amstrong. (2012). Principles Of Marketing, Global Edition (14th ed.). Pearson Education. 
Kotler, P. (2011). Manajemen pemasaran dan analisis perencanaan, implementasi dalam perencanaan (11th ed.). Jakarta: Erlangga.

Kusuma. (2016). citra toko adalah suatu totalitas kesan yang berada dalam memori konsumen tentang persepsi kualitas dari suatu produk barang dan jasa.

Lasander, C. (2013). Citra Merek Kualitas Produk, dan Promosi Pengaruhnya Terhadap Kepuasan KonsumenPada Makanan Tradisional (Survey Pada Industri Rumah Tangga Dodol Daging Pala Audia di Tahuna Kab.Sangihe).

Laura, N., \& Ringo, S. N. S. (2017). INTERVENING Keywords : Latar Belakang Masalah Pemasaran memiliki peranan penting di dalam suatu perusahaan , karena pemasaran jantung dan menjadi ujung hidup tombak No Merek Sepeda Motor Yang Digunakan Honda Matic Yamaha Matic Suzuki Matic Jumlah perusaha. Journal of Management and Business Review, 14(2), 258284.

Lupiyoadi, R. (2001). Manajemen Pemasaran Jasa (1st ed.). Jakarta: Salemba Empat.

Maslow. (2007). Motivasi dan Kepribadian: Teori Motivasi dengan Ancangan Hirarki Kebutuhan Manusia. Jakarta: PT. Pustaka Binaman Pressindo.

Megarita, Gusdyan, \& Tony. (2014). Pengaruh Kualitas Produk Terhadap Citra Merek dan Dampaknya Terhadap Perilaku Pembelian Produk Susu Merek Ultra Milk di Jakarta Utara. Jurnal Manajemen Pemasaran

Mufarrih, Z. (2015). Periklanan Sebuah Pendekatan Praktis.

Noerchoidah. (2013). Analisis Pengaruh Harga, Kualitas Produk Dan Iklan Terhadap Brand Image Dan Keputusan Pembelian Sepeda Motor Merek Kawasaki. Jurnal WIGA, 3(1).

Nuraini, A. (2015). Pengaruh Celebrity Endorser dan Kualitas Produk Terhadap Keputusan Pembelian Melalui Citra Merek Pada Kosmetik Wardah di Kota Semarang.

Puspita, Diestutiace, L., Yulianto, E., \& Sunarti. (2016). Pengaruh Kualitas Produk Dan Word of Mouth terhadap Keputusan Pembelian (Survei Kepada Konsumen Charles \& Keith di Tunjungan Plaza Surabaya). Jurnal Administrasi, 79-85.

Rangkuti, F. (2005). Teknik Mengukur dan Strategi Meningkatkan Kepuasan Pelanggan. Jakarta: Teknik Mengukur dan Strategi Meningkatkan Kepuasan 
Pelanggan.

Rizan, M., Basrah, \& Yusiyana. (2012). Pengaruh Brand Image dan Brand Trust Terhadap Brand Loyalty Teh Botol Sosro Survey Konsumen Teh Botol SosroDi Food Court Itc Cempaka Mas, Jakarta Timur. Jurnal Riset Manajemen Sains Indonesia (JRMSI), 3(1), 1-17.

Roslina. (2010). Citra Merek: Dimensi, Proses Pengembangan Serta Pengukuranya. Jurnal Bisnis Dan Manajemen, 6(3).

Saraswati, R. (2014). Pengaruh Brand Image Terhadap Pengambilan Keputusan Pembelian Ulang Produk Herbalife (Studi Kasus pada Lima Rumah Sehat Bekasi Utara).

Schiffman, L., \& Kanuk, L. (2010). Consumer Behavior. Pearson.

Shahrinaz, I., Kasuma., J., Yacob., Y., Rahman, D. H. A. A., \& Mahdi, A. F. (2016). Relationship and Impact Of E-WOM and Brand Image Towards Purchase Intention Of Smartphone. Journal Of Scientifc Research And Development, 3(5).

Sundalangi, M., Mandey, S. L., \& Jorie, R. J. (2014). Kualitas Produk, Daya Tarik Iklan, Dan Potongan Harga Terhadap Minat Beli Konsumen Pada Pizza Hut Manado.

Tariq, M., Nawaz, M. R., Nawaz, M. M., \& Butt, H. A. (2013). Customer Perceptions about Branding and Purchase Intention: A Study of FMCG in an Emerging Market. Journal of Basic and Applied Scientific Research, 3(2), $340-347$.

Thakur, S., \& Singh. (2012). Brand Image, Customer Satisfactionand Loyalty Intention: A Study in The Context of Cosmetic Product Among The People of Central India. International Journal of Multidisciplinary Management Studies, 2(5), 22498834.

Triastuti, F. (2012). Analisis Pengaruh Kualitas Pelayanan, Kualitas Produk dan Promosi Penjualan terhadap Minat Beli Ulang.

Wahid, M. A. (2016). Analisis Pengaruh Kualitas Produk Terhadap Keputusan Pembelian Melalui Citra Merek dan Nilai Pelanggan (Studi Pada Pengguna Motor Matik Suzuki NEX FI).

Wijaya, T. (2015). Pengaruh Service Quality Perception dan Satisfaction Terhadap Repurchase Intention. Modus Jurnal Ekonomi Dan Bisnis, 17(1).

www.bps.go.id. (n.d.). 
Ketut Joni Santika, Peran Brand Image...

Yaqian, Z. (2011). The Impact of CostumerBased Brand Equity on Revisit Intentions: An Empirical Study of Five Sahanghai Budget Hotels. AUGSB EJournal (Online), 4(1). 